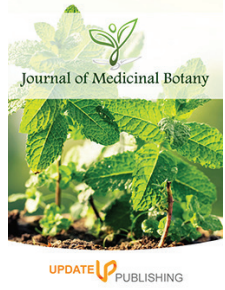

ISSN: $2521-3903$

\title{
In vitro egg hatchability inhibition effect of Albizia gummifera, Phytolacca dodecandra, and Vernonia amygdalina against natural infection of ovine GIT nematodes
}

\author{
Bizuneh Tsehayneh"*, Achenef Melaku² \\ 'Bahir Dar University, College of Agriculture and Environmental Sciences, Department of Veterinary Science, Bahir \\ Dar, Ethiopia, ${ }^{2}$ University of Gondar, School of Veterinary Medicine and animal science, Department of Veterinary \\ Medicine, Gondar, Ethiopia
}

\begin{abstract}
An in-vitro experiment was carried out to evaluate the egg hatching inhibition effect of three herbal plants, namely; Albizia gummifera, Phytolacca dodecandra, and Vernonia amygdalina. The leaves of these plants were collected; air dried and powdered with pestle and mortar, and then hydro-alcoholic extraction was performed and in measuring the percentage yield, P. dodecandra givesbetter yield (15.34\%). Crude extract of these plants were evaluated for egg hatchability assay at different concentrations $(3 \mathrm{mg} / \mathrm{ml}, 5 \mathrm{mg} / \mathrm{ml}$ and $10 \mathrm{mg} / \mathrm{ml}$ ) for each plant and the experiment was replicated five times. Ivermectin $(0.1 \mathrm{ml} / \mathrm{ml})$ was used as positive control. Amon AQl:Kindly provide any one corresponding author email id $\mathrm{g}$ the plants, the crude extracts of P. dodecandrahad better activity that achieved maximum (100\%) egg hatch inhibition at concentrations of $5 \mathrm{mg} / \mathrm{ml}$ while V. amygdalina and A. gummifera induced complete inhibition at concentration of $10 \mathrm{mg} / \mathrm{ml}$ after 48 hours of exposure. All the three plant crude extracts were inhibit egg hatchability significantly $(\mathrm{p}<0.05)$ as compared with the negative control but the inhibition among them were not significantly different in the effect. In conclusion, this study revealed that all of the three plant extracts have high inhibition potential on the hatchability of gastrointestinal nematode eggs. More detailed study on vivo anthelmintic effects of these plants with different extraction methods and phytochemical screening should be done.
\end{abstract}

B. Tsehayneh
Email: mbalew2@gmail.com,
tbeyene11@gmail.com

KEYWORDS: Albizia gummifera;Phytolacca dodecandra;Vernoniaamygdalina

\section{INTRODUCTION}

Helminth infections are among the most economically significant diseases of small ruminants worldwide [1]. In the Developed world, the greatest impact parasitic diseases is probably found in the costs of control, while in Developing one, the impact lies in productivity losses [2]. Ethiopia ranks third in numbers of sheep and goats among Africa nations and ranks eighth in the world [3]. However, gastrointestinal nematode infection has greatest impact on the survival and productivity of sheep and goats [4]. The greatest losses associated with nematode parasite infections can be direct due to a drop in production and other parasite-related penalties [5].

Control of nematode parasites has been based on the use of commercial anthelmintic drugs. However, due to repeated use of these drugs, resistance against drugs is an issue [6,7]. Therefore, investigation of alternative to commercially available drugs like medicinal plants has paramount importance. In Ethiopia, studies are less to scientifically explore, evaluate, document and promote these medicinal plants in the country for their claimed activities $[7,8]$.

The aim of this study was to assess the in vitro egg hatchability inhibition effect of Albizia gummifera, Phytolacca dodecandra, and Vernonia amygdalina against natural infection of ovine GIT nematodes.

\section{MATERIALS AND METHODS}

\section{Study Area}

The study was conducted in Gondar University veterinary laboratory, North Gondar Zone, Amhara Regional State, Northwest Ethiopia. Gondar is located $738 \mathrm{~km}$ North West of Addis Ababa

Copyright: (-) The authors. This article is open access and licensed under the terms of the Creative Commons Attribution License (http://creativecommons.org/licenses/by/4.0/) which permits unrestricted, use, distribution and reproduction in any medium, or format for any purpose, even commercially provided the work is properly cited. Attribution - You must give appropriate credit, provide a link to the license, and indicate if changes were made. 
which is found between geographically coordinates of $12^{\circ}$ to $40^{\circ} \mathrm{N}$ longitude and $37^{\circ}$ to $45^{\circ} \mathrm{E}$ latitude with an altitude range of 1800 2200 meter above sea level. The ranges of maximum and minimum temperature vary between $22-30.7^{\circ} \mathrm{C}$ and $12.3-17.1^{\circ} \mathrm{C}$, respectively. The area receives average annual precipitation of $1000 \mathrm{~mm}$ [9].

\section{Plant Material Collection}

Leaves of Albizia gummifera; Phytolacca dodecandra and Vernonia amygdalina were collected in Gondar University Atse Tewodros campus. The collected plant parts were identified plant taxonomist and allowed to air dried at room temperature, powdered using pestle and mortar, and stored until extraction.

\section{Plant Extraction Method}

Hydro-alcoholic extraction was performed as explained previously [7].

\section{Collection of Parasitic Eggs}

Faecal pellets were collected from the rectum of naturally infected sheep which was maintained in heavily contaminated pastures and was untreated for at least six months. The sample was placed in a sampling bottle and transported immediately to Gondar University veterinary parasitology laboratory. For further analysis, the parasitic egg was collected and the number of eggs per ml was determined based on the brief explanation of Getachew et al. [7].

\section{Egg Hatch Inhibition Assay}

The Egg Hatch Assay was conducted according to the World Association for The Advancement of Veterinary Parasitology guidelines [10] as decribed by Eguale et al. [8].

\section{Data Management and Statistical Analysis}

The experimental data was recorded in Excel spreadsheet subjected to descriptive statistical analysis to derive mean and standard deviation. The hatchability inhibition effect of the extracts of the plants was compared by Analysis of Variance (ANOVA). Further individual mean significant difference was calculated by using post hoc test LSD (Least Significant Difference test) by using SPSS software.

\section{RESULTS}

Among the plants used in this study, P. dodecandra givesbetter yield (15.34\%) as compared to A. gummifera and V. amygdalina (Table 1).

After 48 hours, in vitro exposure of parasitic eggs to different concentrations of hydro-alcoholic plant extracts produced high egg hatch inhibition proportions that were dose-dependent as compared to the negative control. The extracts showed good hatchability inhibition activities against eggs of ovine GIT nematodes. Maximum concentration $(10 \mathrm{mg} / \mathrm{ml})$ induced $100 \%$ egg hatch inhibition (Table 2). Extract of $P$. dodecandra induced $100 \%$ egg hatch inhibition at its second minimum concentration
Table 1: Percentage yield of different plants extracts

\begin{tabular}{lllc}
\hline Plant species & $\begin{array}{l}\text { Plant parts } \\
\text { used }\end{array}$ & Extract type & $\begin{array}{c}\text { Percentage } \\
\text { yield }(\%)(\mathrm{w} / \mathrm{w})\end{array}$ \\
\hline A. gummifera & Leaves & Hydro-alcoholic & 11.67 \\
P. dodecandra & Leaves & Hydro-alcoholic & 15.34 \\
V. amygdalina & Leaves & Hydro-alcoholic & 14.23 \\
\hline
\end{tabular}

of $5 \mathrm{mg} / \mathrm{ml}$ while $\mathrm{V}$. amygdalina revealed $98.62 \%$ inhibition at both $3 \mathrm{mg} / \mathrm{ml}$ and $5 \mathrm{mg} / \mathrm{ml}$ concentrations. Among all plant tested, extract of A. gummifera was relatively the weakest that induced $86.14 \%$ egg hatch inhibition at concentration of $3 \mathrm{mg} / \mathrm{ml}$ and it resulted $97.9 \%$ egg hatch inhibition concentration of $5 \mathrm{mg} / \mathrm{ml}$. The positive control (ivermectin) exhibited relatively good result and induced $100 \%$ egg hatch inhibition at a concentration of $0.1 \mathrm{ml} / \mathrm{ml}$.

$$
\mathrm{SE}^{*+}=\text { standard error }
$$

The result of this revealed that all plants induced egg hatch inhibition statistically significant differences between negative control and different concentrations all plant extracts but there were no significant difference between different concentrations and positive control. Among all plants different concentrations, only A. gummifera show statistically significant difference at its $3 \mathrm{mg} / \mathrm{ml}(\mathrm{p}=0.041)$.

Egg hatch inhibition of plant extracts after 48 hours exposure to different concentration

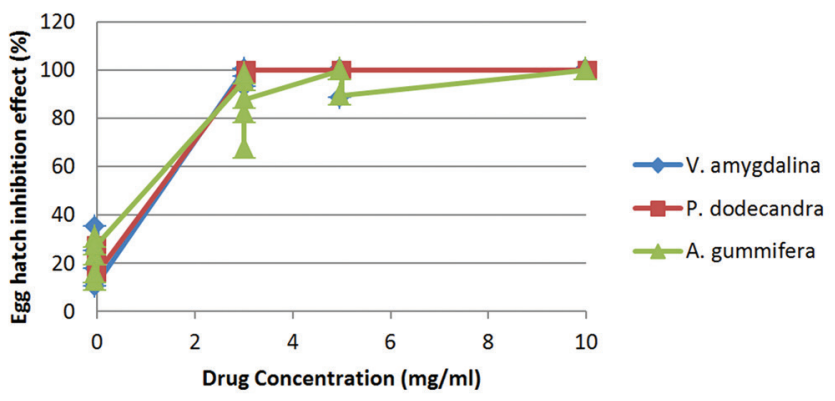

\section{DISCUSSION}

This research was conducted in vitro due to the reason that in vitro technique had advantage to evaluate anthelmintic activities of claimed medicinal plants over in vivo techniques due to simplicity and cost effectiveness of this technique [11].

The findings of the present study revealed that all plant extracts exhibit anthelmintic effect at different concentrations and the efficacy of extracts increased with increasing concentration. The report of Biftu et al. [12] indicated that the sheep with mixed natural infections treated with A. gummifera exhibited significant faecal egg reduction and the this study confirms the anthelmintic property of this plant extract by evaluating the in vitro effect of this plant against mixed infection of sheep [13]. However, the finding of this research even in its minimum concentration $(3 \mathrm{mg} / \mathrm{ml})$ is far from the report of Chufamo et al. [14] that $70 \%$ acetone extract of A. gummifera induced only $48.9 \%$ in vitro egg hatch inhibition against H. Contortus. 
Table 2: Mean percentage inhibition of egg hatch of ovine GIT nematodes after 48 hours exposure to different concentration of plant extracts $(\mathrm{mg} / \mathrm{ml})$

\begin{tabular}{lcccc}
\hline \multicolumn{4}{l}{ Mean \pm SE* percentage inhibition at different concentration } & \\
\hline Plant type & Negative control & 3 & 5 & 10 \\
\hline A. gummifera & $21.7 \pm 3.4125$ & $86.14 \pm 5.459$ & $97.9 \pm 2.1$ & $100 \pm 0.00$ \\
P. dodecandra & $21.64 \pm 2.7458$ & $99.4 \pm 0.4$ & $100 \pm 0.00$ & $100 \pm 0.00$ \\
V. amygdalina & $19.38 \pm 4.5587$ & $96.42 \pm 1.68$ & $97.64 \pm 2.36$ & $100 \pm 0.00$
\end{tabular}

$\mathrm{SE}^{*}=$ standard error

The results of this study showed that $P$. dodecandra has higher anthelmintic potential. According to Mohammed et al. [15], in vitro anthelmintic effect of $P$. dodecandra resulted $99.4 \%$ inhibition of egg hatchability at a concentration of $0.1 \mathrm{mg} / \mathrm{ml}$ which is compatible with the result of this study even if the concentration is different and $68.1 \%$ of adult mortality of H. contortus at concentration of $4 \mathrm{mg} / \mathrm{ml}$. The report of Innocent and Deogracious [16] supports this result idea that $P$. dodecandra exhibited $100 \%$ ascaricidal effect at a concentration of $10 \mathrm{mg} /$ $\mathrm{ml}$ after 48 hours of in vitro test.

The results of V. amygdalina in this study support the trials by the traditional healers that these plants treat helminth infections in livestock [17]. The good anthhelmintic potential of V. amygdalina observed in this research is supported by the report of Adediran and Uwalaka [18] that the plant had 100\% faecal egg count reduction effect against goat's helminth parasites. However, the report of Nalule et al. [17], and Innocent and Deogracious [16] is far from the findings of this study which states that this plant reveals only $64 \%$ faecal egg reduction count against mixed infection of goat's worm and kills $50 \%$ of the parasite at $6 \mathrm{mg} / \mathrm{ml}$ respectively. Moreover, this finding contradicts with the result reported by Alawa et al. [19] and Sawleha [20] that states V. amygdalina did not show any significant in vitro anthelmintic activity at concentrations up to $11.2 \mathrm{mg} / \mathrm{ml}$.

\section{CONCLUSION AND RECOMMENDATIONS}

In this study, extracts of both study plants (V. Amygdalina and A. gummifera) have shown promising in vitro activity against eggs of ovine GIT nematodes. Depending on the egg hatch inhibition efficacy of these plant extracts, $V$. Amygdalina more potent than A. gummifera. This study supports the idea of pastoral communities and traditional healers in use of plant anthelmintics and to justify their potential of traditional and ethno-veterinary use of medical plants. From our results, below recommendations can be done:

- These plants should be tested with other types of extraction methods and further should be evaluated in vivo.

- Other different parts (flowers, fruits, stems and roots) of those plants should be evaluated for their anthelmintic effect in vitro as well as in vivo.

\section{REFERENCES}

1. Holm SA, Sörensen CR, Thamsborg SM, Enemark HL. Gastrointestinal nematodes and anthelmintic resistance in Danish goat herds. Parasite. 2014;21.

2. Perry BD, Randolph TF. Improving the assessment of the economic impact of parasitic diseases and of their control in production animals. Veterinary parasitology. 1999;84(3-4):145-68.

3. Central Stastical Agency. Livestock resources and production stastics in Ethiopia. Agricultural sample enumeration. Central Statistical Authority of the Federal Democratic Republic of Ethiopia. Addis Ababa, Ethiopia: CSA; 2008.

4. Perry BD., Randolph TF., McDermott JJ., Sones KR. and Thornton PK. Investing in animal health research to alleviate poverty. ILRI, Nairobi, Kenya. 2002.

5. Vatta AF, Letty BA, Van der Linde MJ, Van Wijk EF, Hansen JW, Krecek RC. Testing for clinical anaemia caused by Haemonchus spp. in goats farmed under resource-poor conditions in South Africa using an eye colour chart developed for sheep. Veterinary Parasitology. 2001;99(1):1-4.

6. Sutherland IA, Leathwick DM. Anthelmintic resistance in nematode parasites of cattle: a global issue?. Trends in parasitology. 2011;27(4):176-81.

7. Getachew S, Ibrahim N, Abebe B, Eguale T. In vitro evaluation of Anthelmintic activities of crude extracts of selected medicinal plants against Haemonchus contortus in AlemgenaWereda, Ethiopia. Acta ParasitologicaGlobalis. 2012;3:20-7.

8. Eguale T, Tilahun G, Gidey M, Mekonnen Y. In vitro anthelmintic activities of four Ethiopian medicinal plants against Haemonchus contortus. Pharmacologyonline. 2006;3:153-65.

9. Ministry of Agriculture(MoA). Budgeting and planning reports, summary of MoA, North Gondar zone, 2004.

10. Coles GC, Bauer C, Borgsteede FH, Geerts S, Klei TR, Taylor MA, Waller PJ. World Association for the Advancement of Veterinary Parasitology (WAAVP) methods for the detection of anthelmintic resistance in nematodes of veterinary importance. Veterinary parasitology. 1992; 44(1-2):35-44.

11. Remison SU. Arable and vegetable crops of the tropics. Gift-Print Associates, Benin-City. 2005;45-50.

12. Biftu D, Nurfeta A, Jobre Y. Evaluation of anthelmintic activities of crude leaf extracts of three indigenous herbal plants against ovine gastrointestinal nematodosis.2004

13. Chufamo B, Kechero $Y$, Bekele M,Beyene A. Comparison of the Efficacy of Different Modes of Extraction of 5 Tannin Rich Plants on Haemonchus contortus: Searching for Indicators Based on A Range of In vitro assays. Global Veterinaria.2013;11 (6):762-765.

14. Chufamo B, Kechero $Y$, Bekele M,Beyene A. Comparison of the Efficacy of Different Modes of Extraction of 5 Tannin Rich Plants on Haemonchus contortus: Searching for Indicators Based on A Range of In vitro assays. Global Veterinaria.2013;11 (6):762-765.

15. Mohammed A, Wossene A, Giday M, Tilahun G, Kebede N. In vitro anthelminthic activities of four medicinal plants against Haemonchus contortus. African Journal of Plant Science. 2013;7(8):369-73.

16 Innocent $\mathrm{T}$, Deogracious $\mathrm{O}$. The anthelmintic activity of selected indigenous medicinal plants used by The Banyankole of Western Uganda. Journal of animal and veterinary advances. 2006;5(8):712-7.

17. Nalule AS, Mbaria JM, Olila D, Kimenju JW. Ethnopharmacological practices in management of livestock helminthes by pastoral communities in the drylands of Uganda. Livestock Research for Rural Development. 2011;23(2):1-27.

18. Adediran OA, Uwalaka EC. Effectiveness evaluation of levamisole, albendazole, ivermectin, and Vernonia amygdalina in West African Dwarf goats. Journal of parasitology research. 2015: 1-5.

19. Alawa CB, Adamu AM, Gefu JO, Ajanusi OJ, Abdu PA, Chiezey NP, Alawa JN, Bowman DD. In vitro screening of two Nigerian medicinal plants (Vernonia amygdalina and Annona senegalensis) for anthelmintic activity. Veterinary Parasitology. 2003;113(1):73-81.

20. Sawleha Q, Dixit AK, Dixit P. Use of medicinal plants to control Haemonchus contortus infection in small ruminants. Veterinary World. 2010;3(11):515. 